\title{
Review Terhadap OSF.IO Sebagai Sarana Publikasi Preprint
}

\author{
Rio Aurachman, ${ }^{*}$ \\ *Corresponding author: rioaurachman@telkomuniversity.ac.id \\ ${ }^{1}$ Telkom University; ORCID: 0000-0001-6093-2190
}

\begin{abstract}
Publikasi karya tulis telah memiliki banyak alternait. Salah satu alternatif yang berkembang adalah melakukan publikasi pada preprint server. Kami membandingkan beberapa alternatif preprint menggunakan beberapa kriteria penilaian. Berdasarkan perbandingan yang dilakukan, kami merekomendasikan osf.io sebagai tempat untuk melakukan publikasi tipe preprint. Osf.io memenuhi kriteria kemudahan sitasi dan index pada google scholar. Osf.io juga memenuhi beberapa kriteria penilaian lainnya.
\end{abstract}

Keywords: osf.io, preprint server, publikasi

\section{Pengantar}

Dalam rangka melakukan publikasi yang terbuka dan mudah diakses, beberapa penliti terdorong untuk mulai mempublikasikan karyanya pada beberapa Preprint Server. Terdapat berbagai macam alternati preprint Server. Salah satunya adalah osf.io. Melalui tulisan ini kami akan melakukan proses review bagaimana bentuk layanan dari osf.io. Akan dikaji apakah OSF.io memiliki fitur-fitur yang dibutuhkan oleh peneliti. Khususnya peneliti yang tertarik untuk mempublikasikan karyanya secara terbuka dan secara bebas untuk kemajuan ilmu pengetahuan

\section{Penjelasan Singkat terkait Metode}

Metode yang akan digunakan untuk dilakukan proses review adalah menggunakan studi Pustaka dan studi literatur daring. Tahap pertama kami akan melakukan perbandingan antara beberapa server preprint. Dari perbandingan tersebut akan diambil beberapa server preprint yang dikaji secara lebih mendalam. Setelah itu akan dilakukan pembentukan kriteria penilaian dari setiap server preprint tersebut. Setiap kriteria penilaian memiliki cara untuk mengukurnya. Tahap terakhir adalah membangun sebuah panduan tambahan dalam menggunakan server preprint yang terpilih.

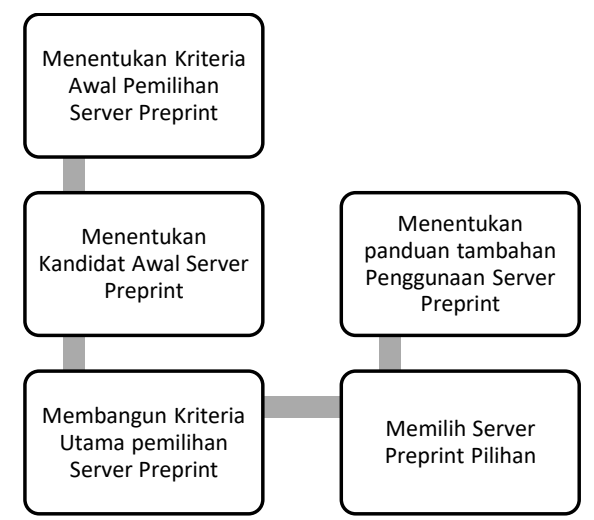

Gambar 1. Metode Penentuan Server Preprint Pilihan

\section{Hasil dan Pembahasan}

Tahap pertama adalah membanun kriteria awal untuk memnetukan server preprint pilihan. Krietria yang kami gunakana dalah server preprint tersebut cukup umum dan tidak spesifik untuk bidang 
keilmuan tertentu. Hal tersebu dikarenakan akan memberikan kebebasan kepada penulis untuk memberikan pemikiran dan hasil penelitian apapun yang dirasa perlu untuk dipublikasikan tanpa merasa khawatir dengan topik yang dibatasi. Beberapa halaman website telah menampilkan beberapa diskusi dan pemaparan terntang alternatif preprint. Salah satu proses diskusi yang komprehensif ada pada menu Q\&A dari researchgate [researchgate]. Beberapa daftar yang dipaparkan pada page tersebut, diantaranya adalah sebagai berikut:

1. Research Preprint Server List []

2. Rising tide Preprint Server []

Berdasarkan beberapa alternatif yang dipaparkan di sana, kami lakukan pemilihan server preprint yang sesuai dengan kriteria awal yaitu memiliki cakupan ilmu yang umum, luas dan general. Beberapa server preprint tersebut adalah

1. PeerJ Preprints

2. Preprints (MDPI)

3. Figshare

4. Zenodo

5. F1000Research

6. Authorea / Winnower

7. HaL

8. Researchgate

9. Osf.io

Dari beberapa alternatif tersebut perlu dipilih server yang memiliki fitur yang diharapkan. Sebelumnya akan ditentukan terlebih dahulu kriteria yang digunakan untuk memilih. Kriteria utama dalam pemilihan server tersebut adalah sebagai berikut

1. Cakup ilmu yang general

2. Terindex pada Google scholar

3. Proses index pada google scholar cukup cepat

4. Memungkinkan menulis dalam beberapa Bahasa

5. Artikel yang diupload pada preprint dapat disitasi

6. Sitasi yang dilakukan pada paper preprint tersebut diharapkan terhitung sebagai penjumlahan Sitasi

7. Memiliki DOI

8. Memiliki link

9. Terdapat kebebasan yang cukup untuk melakukan publikasi tanpa dibatasi oleh proses moderasi dan review yang bertele-tele

Kriteria terebut diukur dengan cara melakukan uji coba langsung terhadap setiap server preprint. Salah satu cara yang digunakan adalah menguji satu buah paper yang ada pada preprint dan lalu melihat apakah terdapat paper tersebut juga pada google scholar. Beberapa server ternyata tidak dapat memnuhi kriteria tersebut. Kriteria sitasi juga dilihat pada google scholar. Beberapa preprint ternyata juga tidak dapat disitasi. Researchgate sebagai contoh, preprint dapat mensitasi paper lain di luar researchgate tapi ternyata bila mensitasi preprint researchgate sendiri tidak akan terhitung. Kami melakukan uji coba tersebut pada paper kami (Aurachman, Analytical Hierarchy Process Sebagai Tools untuk Menentukan Pasangan Hidup, 2020) (Aurachman, Konsep Probabilitas untuk Memodelkan Resolusi Antara Ikhtiar, Tawakal, dan Doa dalam Menghadapi Wabah Covid19, 2020) Salah satu analisis penyebab yang kamii temukan adalah dimungkinkan karena paper researchgate pada google scholar tidak memuat informasi tahun terbit. Kriteria kecepatan index kami evaluasi dengan cara melihat apakah paper yang terbit pada tanggal hari ini sudah terindex pada google scholar. Beberapa preprint ternyata butuh waktu yang lebih lama, bahkan hingga beberapa pekan. 
Proses moderasi dan review dievaluasi dengan cara melihat tata cara submit yang dimunculkan oleh website preprint.

Berdasarkan kriteria-kriteria tersebut, server preprint yang kami nilai terbaik untuk sampai saat ini adalah server preprint osf.io. Osf.io memiliki beberapa fitur penting yang diulas dalam daftar kriteria. Paper yang dipublish pada Osf.io dengan tempo yang cepat segera muncul pada google scholar. Sebagai contoh paper utami membutuhkan lima hari sejak pertama kali upload di osf.io hingga lalu terdata dalam google scholar (Utami, 2020). Tertulis tanggal upload adalah 11 Mei 2020 di osf.io. pada saat kami melakukan pengecekan pada google scholar tanggal 16 Mei 2020, paper tersebut sudah tercantum dalam google scholar. Paper yang diupload pada osf.io pun dapat disitasi serta sitasi tersebut terdata pada google scholar. Sebagai contoh paper berjudul "FBXL8 is differentially expressed and transcriptionally induced in MERS coronavirus infection" (Mamoor, FBXL8 is differentially expressed and transcriptionally induced in MERS coronavirus infection., 2020) dipublikasikan hanya pada osf.io. Paper tersebut ditsitasi oleh paper lain yang juga dipublikasikan pada osf.io berjudul "IL6 and IL1RN is differentially expressed and transcriptionally induced in models of SARS coronavirus infection" (Mamoor, IL6 and IL1RN is differentially expressed and transcriptionally induced in models of SARS coronavirus infection., 2020) oleh penulis yang sama, pada tahun yang sama. Hal tersebut memungkinkan terbangunnya jejaring penelitian dengan lebih cepat. Sitasi juga dapat dilakukan tidak hanya oleh sesame osf.io tetapi oleh paper dari jurnal lain sebagai contoh paper berjudul The Scholarly Commons-principles and practices to guide research communication (Bosman, et al., 2017), juga disitasi oleh paper di jurnal lain. Sitasi tersebut dihitung dan diakumulasi pada paper dan juga pada profil penulisnya. Sitasi tersebut perlu menuliskan link paper pada daftar Pustaka. Sebagai contoh dapat ditulis dalam bentuk alternatif di antara berikut atau ketiganya sekaligus:

1. kode DOI seperti "doi: 10.31219/osf.io/g564w"

2. link akses yang memuat DOI https://doi.org/10.3897/rio.2.e9340

3. link akses terhadap website https://osf.io/preprints/weqsf/

Sejauh ini kami belum berhasil menemukan proses sitasi yang menampilkan tanpa link atau DOI nya. Perlu diuji coba pula pada preprint researchgate menggunakan link. Osf.io juga tidak mensyaratkan suatu moderasi yang memakan waktu lama pada saat melakukan proses upload dari paper. Osf.io juga memungkinkan dilakukan proses penerbitan dengan menggunakan Bahasa apapun (Utami, 2020). Kami menemukan beberapa paper osf.io mengunakan Bahasa arab dan Bahasa itali.

\section{Kesimpulan dan Saran}

Berdasarkan proses yang telah dilakukan, didapatkan kesimpulan sementara bahwa OSF.IO kami rekomendasikan untuk digunakan sebagai sarana untuk mempublikasikan tulisan. Osf.io memenuhi kriteria-kriteria yang telah dibangun. Dapat dilakukan analisis lebih lanjut setelah dilakukan eksperimen upload di server osf.io. Selain itu dapat dilakukan analisis lebih lanjut menggunakan kriteria lainnya.

\section{References}

Aurachman, R. (2020). Analytical Hierarchy Process Sebagai Tools untuk Menentukan Pasangan Hidup. doi:10.13140/RG.2.2.12500.14724

Aurachman, R. (2020). Konsep Probabilitas untuk Memodelkan Resolusi Antara Ikhtiar, Tawakal, dan Doa dalam Menghadapi Wabah Covid19. http://dx.doi.org/10.13140/RG.2.2.12500.14724

Bosman, J., Bruno, I., Chapman, C., Tzovaras, B. G., Jacobs, N., Kramer, B., . . others. (2017). The Scholarly Commons-principles and practices to guide research communication. https://doi.org/10.31219/osf.io/a4nr5

Mamoor, S. (2020). FBXL8 is differentially expressed and transcriptionally induced in MERS coronavirus infection.

Mamoor, S. (2020). IL6 and IL1RN is differentially expressed and transcriptionally induced in models of SARS coronavirus infection. 
Utami, W. S. (2020). Perangkat Lunak (Software) Pada Komputer. doi:10.31219/osf.io/a4nr5

Aurachman, R. (2018). Perancangan Influence Diagram Perhitungan Dampak Dari Revolusi Industri 4.0 Terhadap Pengangguran Kerja. Jurnal Teknologi dan Manajemen Industri, 4(2), 7-12

https://www.inlexio.com/rising-tide-preprint-servers/

https://www.researchgate.net/post/What_are_alternative_repositories_like_arXivorg

https://www.researchgate.net/profile/Prathamesh_Deshmukh/post/What_are_alternative_reposit ories_like_arXivorg/attachment/5bf7066f3843b00675469435/AS\%3A695853014597632\%40154291 5695028/download/Research+Preprints-+Server+List.pdf 